\title{
Investment In The Greek Processing Of Agricultural Products And Food: A Panel Data Approach
}

Nicholas C. Baltas, (E-mail: baltas@ aueb.gr), Athens University of Economics and Business, Greece

\begin{abstract}
The aim of this research is to quantify Greek investors' behaviour in the industry of processing agricultural products and food at the aggregate level for all sectors and all regions over the period 1981-1999. The focus of this study is to investigate empirically the effectiveness of the EU and national policies concerning investment incentives in the processing of Greek agricultural products. Investors' behaviour is examined by employing a synthesized traditional model. The dynamic model is estimated using alternative dynamic panel data methods, GMM and ML techniques. EU and national subsidies are instrumental in stimulating agricultural investments in the past decades, followed by investors' expectations and, in most of the cases, investment lagged by one year. The empirical results obtained by ML by GMM are very similar, with the exception that the t-statistics are higher in the former case. Moreover, there is no evidence for autocorrelation or dynamic misspecification.
\end{abstract}

\section{INTRODUCTION}

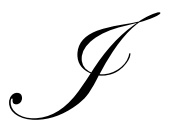

n 1998, the output value of the EU food, drink and tobacco industry was almost 600 billion ECU, about 15 per cent of total manufacturing output. An international comparison of the industry reveals that the EU is the world's largest producer of food, drink and tobacco products, followed by the USA and Japan with 460 and 260 billion ECU respectively (E.C., 2002).

The food and drinks sectors occupy the first place in Greek manufacturing industry in terms of value added. The share of food and drinks in total manufacturing industry value added reached 24.7 per cent in 1998 . The average size of employment in food and drinks establishments is 5.2 persons per unit and is similar to that for manufacturing industry in general (4.9). Exports and imports of food and drinks increased during the 1980-95 period. However, imports increased faster than exports. As a result, the positive balance of trade turned negative. Although demand for food increased between 1980 and 1998, the share of private expenditure for food in total private expenditure decreased by 8.5 percentage points (thanks to correspondingly low elasticities). The corresponding share for drinks increased by one percentage point during the 1980-90 period and has remained constant since then. The food sector exhibits high intensity in raw material use (53 percent) and low intensity in capital use ( 22.6 percent). The opposite is true for drinks sector (30.3 percent and 32.7 percent respectively). These figures refer to the year 1996, CICA (1997).

Economic incentives for the "development of processing and marketing of agricultural products" are offered by three ministries: Agriculture, National Economy and Development. Investments in the processing of agricultural products and food are subject to EU regulations, national development laws and related ministerial decisions.

EU regulations, which are implemented by the Ministry of Agriculture and have successively replaced the previous ones (EU 951/97, EEC 3669/93, EEC 866/90, EEC 35/77), provided for grants covering 30-60 per cent of the cost of investment, depending on region and sector. Financing came from national and EU sources. 
The financial incentives offered by the Ministry of National Economy are provided by Law 2601/98, which replaced previous ones (2234/94, 1892/90 and 1262/82). Law 1892/90 introduced two alternative sets of incentives: (i) grants covering part of the cost of investment ranging between 0-50 per cent, subsidisation of interest rates ranging between 15-50 percent and accelerated depreciation charges or (ii) deductions from profits tax and accelerated depreciation charges. The latest Law 2601/98 modified the two alternative sets of incentives as follows: (i) investment grants or/and subsidised interest rates for investment loans or/and financial leasing and (ii) tax allowance and subsidised interest rates for investment loans.

The Ministry of Development provided countrywide grants ranging between 35-40 per cent of the cost of investment (Law 2234/94, which replaced Law 1892/90).

The percentage of investment financed by grants during the 1981-99 period was the following: 64 per cent by the Ministry of Agriculture, 20 percent by the Ministry of National Economy and 16 percent by the Ministry for Development. The corresponding percentage of the number of investment projects were 63, 31 and 6 per cent.

The aim of this research is to quantify Greek investors' behaviour at aggregate level for all sectors and all regions over the period 1981-1999. The focus of this study is to investigate empirically the effectiveness of the EU and national policies concerning investment incentives in the processing of Greek agricultural products. Investors' behaviour is examined by employing a synthesized traditional model. The traditional model is estimated using alternative panel data methods. First, the dynamic panel data model is estimated with a common intercept by employing the Generalized Method of Moments (GMM). The dynamic panel data formulation is also estimated using the Maximum Likelihood (ML) estimation technique.

The study consists of six sections. In Section 2, a review of the literature on investment theories is presented, followed by an exposition of the investment expenditure model employed in order to explain investors' behaviour in the agricultural products and food processing industry. The data used for conducting the empirical analysis is panel data, being a combination of the 13 regions for the 11 main sectors of the food industry for the 1981-99 period. The sample selection method of the data used is given in Section 3. In Section 4, the dynamic panel data model with a common intercept and with fixed and random effects are presented. The empirical results obtained by the two methods with respect to private investment in the processing agricultural products and food for all sectors and for all regions are compared. Finally, the main findings are summarized and some policy implications are drawn in Section 6.

\section{INVESTMENT EXPENDITURE}

Specification of desired capital has been based on four major theories. The first is Clark's approach (1917), known as capacity utilization, which assumed that desired capital is proportional to output because a firm's incentive to invest will increase with the output produced by capital. The second one, which applies specifically to agriculture, is Girao, Tomek, and Mount's (1974), who found that the change in output between periods more appropriately captures the demand for investment. Third, Tinbergen (1938) proposed an alternative theory in which investment depends on the level of expected future profits. Higher profitability increases future expectations - which in turn stimulate current investment - and may also ease any constraints on the supply of funds to finance expansion.

Part of the rationale for using expected profitability involves the importance of internal liquidity. According to Campbell (1958), this "residual funds" hypothesis is relevant to agriculture because the sector comprises mostly of family-based production units. Capital formation is achieved through the direct efforts of individual operators and thus lower profitability and availability of internal funds may prevent attainment of the desired capital stock level much more readily than in an industrial firm which has greater access to outside capital. This approach is known as cashflow model. 
Jorgenson (1971), based on neoclassical theory, developed a model in which owners maximize the present value of their equity under conditions of perfect competition. The optimal capital stock is found by equating the value of the marginal product to its cost. Jorgenson and Siebert (1968) were the first to incorporate the influence of tax structures in the cost of capital.

The traditional investment models have been criticized because they have been based on ad hoc specifications for the adjustment process and desired capital level. More recent models have cast the firm in a dynamic optimization framework in order to derive its investment behaviour equation. Examples are found in Berndt, Buss, and Waverman (1978) and subsequently in LeBlank and Hrubovcak (1985, 1986). Also, Casing and Kollintzas (1991) have found evidence of asymptotic adjustment costs in U.S. manufacturing between capital and labour. Adjustments in capital lower the marginal product of labour. Labour hinders capital adjustment by increasing capital adjustment costs and capital facilitates labour adjustment by lowering labour adjustment costs. This leads to a cyclical adjustment pattern in that labour decreases before capital increases relative to their steady state. There is more recent literature dealing with investment analysis in the food processing sector using methods as error corrections models (Morrison, 1998 and Morisson and Siegel, 1997).

Although dynamic optimisation models of investment behaviour have a more consistent theoretical framework than traditional ones, it is not evident that the former are unambiguously better that the latter. For instance, the results obtained by Weersink and Tauer (1989) indicate that the investment behaviour of New York dairy farmers is better explained by using the traditional approach. Baltas (1999) employed a synthesized traditional model to examine Greek farmers' investment behaviour both at the aggregate level and by broad type of investment. The rational expectations model was alternatively used. From the comparison of the empirical results obtained by the synthesized traditional model with those obtained by the rational expectations model, it is evident, on the basis of economic criteria, that one cannot be in favour of the latter approach.

To examine investment behaviour, we employ a synthesized traditional model. The independent theories were integrated into a single, unified approach, where desired investment $\left(\mathrm{I}_{\mathrm{t}}^{*}\right)$ is a function of capacity utilization, $\Delta \mathrm{Y}_{\mathrm{t}}$ (accelerator), the expected revenues (profits), $Y_{t}$, the nominal interest rate, $r_{t}$, and investment subsidies $S_{t}$. Because there is no unanimous agreement in applied economics on the measurement of expected revenue and no data is available for this variable, alternative variables are used: value added in food industry with a time lag of $n$ years, $\mathrm{Y}_{\mathrm{t}-\mathrm{n}}$, or an implicit price deflator of value added in food industry with a time lag of $\mathrm{n}$ years, $\mathrm{P}_{\mathrm{t}-\mathrm{n}}$.

$I_{t}^{*}=\alpha_{0}+\alpha_{1} \Delta Y_{t}+\alpha_{2} Y_{t-n} \quad$ or $\quad \alpha_{2}^{\prime} P_{t-n}+\alpha_{3} r_{t}+\alpha_{4} S_{t}+u_{t}$

The traditional approach to modelling investment behaviour requires assumptions about the adjustment process and the desired level of capital. Various theories about the adjustment process have been proposed. Koyck (1954) suggested a geometric distributed lag function in which the weights on desired capital decline systematically over time. Jorgenson (1971) developed a class of rational distributed lag functions without restricting the lag to a particular configuration. Treveno and Keller (1974) employed eight functional forms to determine the lag distribution that best explains the time path of farm investment response. They found that the only estimated function acceptable for annual data was $\mathrm{P}(\mathrm{L})=(1+\lambda \mathrm{L})$, which is a simple distributed lag truncated after one period.

As a starting point the desired capital stock is commonly used to examine investment behaviour. Due to the lack of statistical data for capital stock the desired investment level is employed.

It is further assumed that the investor gradually adjusts the actual level of investment to the desired level, depending on progress made in carrying out the investment projects and the availability of finance. The rate of adjustment of investment toward a new equilibrium position depends on the difference between current desired level of investment and past actual level, as well as on the speed of adjustment of the actual level to the desired one: 


$$
\mathrm{I}_{\mathrm{t}}-\mathrm{I}_{\mathrm{t}-1}=\lambda\left(\mathrm{I}_{\mathrm{t}}^{*}-\mathrm{I}_{\mathrm{t}-1}\right)+\mathrm{v}_{\mathrm{t}} \quad 0<\lambda \leq 1
$$

Equation (2) indicates the way by which the actual level of investment adjusts toward its long-run equilibrium. The coefficient $(\lambda)$ represents the proportion of the adjustment toward equilibrium that occurs in a given time period. Substituting Equation (1) into Equation (2) and re-arranging terms, we obtain:

$$
\mathrm{I}_{\mathrm{t}}=\mathrm{b}_{0}+\mathrm{b}_{1} \mathrm{I}_{\mathrm{t}-1}+\mathrm{b}_{2} \Delta \mathrm{Y}_{\mathrm{t}}+\mathrm{b}_{3} \mathrm{Y}_{\mathrm{t}-\mathrm{n}} \quad \text { or } \quad \mathrm{b}_{3}^{\prime} \mathrm{P}_{\mathrm{t}-\mathrm{n}}+\mathrm{b}_{4} \mathrm{r}_{\mathrm{t}}+\mathrm{b}_{5} \mathrm{~S}_{\mathrm{t}}+\varepsilon_{\mathrm{t}}
$$

where

$$
\begin{aligned}
b_{0}= & \alpha_{0} \lambda, \quad b_{1}=1-\lambda, \quad b_{2}=\alpha_{1} \lambda, \quad b_{3}=\alpha_{2} \lambda, \quad b_{3}^{\prime}=\alpha_{2}^{\prime} \lambda, \quad b_{4}=\alpha_{3} \lambda, \quad b_{5}=\alpha_{4} \lambda \\
& \varepsilon_{t}=\lambda u_{t}+v_{t}
\end{aligned}
$$

and $\mathrm{u}_{\mathrm{t}}$ and $\mathrm{v}_{\mathrm{t}}$ are disturbances with zero means and constant variances.

\section{DATA}

The data used for conducting the empirical analysis are panel data. Panel data offer several advantages such as more information content, more variability, less collinearity among variables, more degrees of freedom, more efficiency in estimation, ability to study the dynamics of adjustments across different units, ability to identify and measure effects that are simply not detectable in pure time series data, ability to construct and test more complicated behavioural models and, finally, elimination of biases resulting from aggregation over firms or individuals (although it is necessary to control for heterogeneity across units in panel data estimation). For a recent review of dynamic panel data models refer to Arellano and Honoré (2002).

However, panel data are also subject to a set of limitations which have to be taken into consideration, such as: difficulties in design and data collection, distortions of measurement errors, selectivity problems and short time series dimension (Baltagi, 1996). An additional problem in using panel data is that one can never be sure that parameter homogeneity restrictions are actually correct.

The investment and subsidy data were obtained from the Ministry of Agriculture, the Ministry of National Economy and the Ministry for Development. The database of the ministries is considered as a highly reliable source, which provides data for all investment taking place yearly by region and sector. The data used are annual and cover the period from 1981 to 1999. This period is worth analysing because of the accession of Greece to the European Union / European Community in 1981, which resulted in the immediate implementation of the Common Agricultural Policy (CAP). Moreover, the food and agricultural products sectors have benefited from subsidies and other favourable measures provided by the national development laws. Obviously, these factors have impacted on food manufacturers' investment behaviour.

The regions under consideration are 13 and correspond to the country's administrative division. With regard to the various sectors of food industry, the analysis focuses on 11 main sectors, according to the priorities adopted and applied by the Ministry of Agriculture, the CAP and the national laws. Moreover, these sectors are by far the most important ones in terms of value added, employment, consumption, exports, etc. They cover the overwhelming majority of output of Greek agricultural products and food manufacturing sector. Care has been taken in order to avoid inclusion of investments that, although approved, have never been realized. Since the focus of this study is on realised investment we can safely ignore approved investments that have not been actually realized.

A list of variables employed in the model is given in Appendix. It should be mentioned that the data includes large, medium and small size investments across the regions and sectors leading to a highly heterogeneous data set. Investment patterns are determined to a large extent by the subsidies granted by national and Community sources. It is worth mentioning that there are significant variations between sectors and regions over the 1981-1999 period. Some 
regions have absorbed large amounts of capital in specific sectors whereas others obtained limited amounts which shows their varying potential.

\section{THE DYNAMIC PANEL DATA MODEL}

\section{The Panel Data Model With Common Intercept}

Panel data involve time series observations on the same set of cross-section units. Many issues need to be taken into account when dealing with this type of data. The major concern has to do with the effects that different individuals can have over time. Thus, the purpose of this section is to try to identify the kind of difficulties that may be encountered in dealing with panel data. The data set can be balanced (cases where the individuals are observed over the entire sample period) or unbalanced (incomplete panels are more likely to be the norm in typical economic empirical settings). The dynamic relationship concerning investment expenditure is characterised by the presence of a lagged dependent variable among the regressors. Consider the following standard dynamic linear model which can be expressed as:

$$
\mathrm{y}_{\mathrm{it}}=\alpha_{\mathrm{i}}+\gamma \mathrm{y}_{\mathrm{it}-1}+\mathrm{x}_{\mathrm{it}}^{\prime} \beta+\mathrm{u}_{\mathrm{it}}
$$

where $\quad y_{\text {it }}$ is the value of the dependent variable for cross-section unit $i$ at time $t$,

$\mathrm{i}=1, \ldots, \mathrm{n}, \mathrm{t}=1, \ldots ., \mathrm{T}$ and

$\mathrm{x}_{\mathrm{it}}$ is a $\mathrm{k} \times 1$ vector of observations for the explanatory variables. data. Thus

In the simplest form, the $\alpha_{\mathrm{i}}$ intercept can be identical for all pool members accepting the stacked format of the

$\alpha_{\mathrm{i}}=\alpha$.

This is not a realistic assumption. The estimation of the model with different $\alpha_{i}$ 's is complicated by the fact that $\mathrm{y}_{\mathrm{i}, \mathrm{t}-1}$ and $\mathrm{u}_{\mathrm{it}}$ are correlated when the $\alpha_{\mathrm{i}}$ intercepts are random. In this case, standard Least Squares Dummy Variables (LSDV) procedures are inconsistent. To avoid this problem, the model was estimated both for the Generalized Method of Moments (GMM) and Maximum Likelihood (ML).

\section{Generalised Method Of Moments}

The solution to the dynamic approach model proposed by many authors ${ }^{1}$ (Baltagi, 1996) is to use an instrumental variable estimator. GMM estimators (Arellano and Bond, 1991) allow for heteroskedasticity across units and for possible correlation of the disturbances over time in a dynamic framework. In the estimation, some attention is paid to the validity of the instruments. There are two problems with GMM or instrumental variables methods: first, the instruments should be uncorrelated with the error term, or the orthogonality conditions should be satisfied by the data (this is the exogeneity requirement); second, the instruments should have a strong correlation with the regressors of the model (this is the relevance requirement).

GMM estimates should in principle be preferred for several reasons. First, there is evidence that individual effects are present and that the errors are correlated with the right hand side variables. Second, the right hand side variables in the model are likely to be endogenous with respect to the differenced disturbance, so the use of instrument variables is necessary. Third, the heterogeneity of our data with respect to the size and other characteristics also suggest that estimators which allow for heteroskedastic disturbances such as GMM should be preferred. Finally, GMM allows for consistent standard errors under very general assumptions regarding the error structure.

1 The GMM method is commonly applied on panel data and, more specifically, on firm investment and financial decision making. Muklay et al, (2001) provides an updated review of empirical literature on firm investment decisions which use GMM methodology. 
In the present analysis, the choice of the variables included in the model was made after a careful look at different possibilities. For the GMM estimation, Heteroskedasticity and Autocorrelation Consistent Covariances matrices are used. More particularly, both White and Newey-West consistent covariances matrices are employed. The White covariance matrix assumes that the residuals of the estimated equation are serially uncorrelated. The NeweyWest covariance matrix estimator is consistent in the presence of both heteroskedasticity and seriaal correlation of unknown form. For estimation purposes, we have used the GMM estimation procedure available in EVIEWS.

\section{Empirical Results}

Considering the empirical results obtained for private investment in the processing of agricultural products and food for all sectors, the decisive factors are the subsidies from Community and national resources (Table 1). The corresponding coefficients are by far the most significant ones among the other determining variables. ${ }^{2}$ This reflects the fact that the great majority of investors opted for subsidies rather than for medium and long-term low-interest credit. Investors' expected revenues, expressed by the value added of processing agricultural products and food or, alternatively, by the implicit price deflator of agricultural products and food with a time lag of one year were found to be a statistically significant variable. The partial adjustment coefficient is $\lambda=0.92$, which means that, because of its small scale, investment is more or less completed within a single year. This is due to the fact that the bulks of the subsidies are directed to small-size firms, with short-run investment projects. The overall explanation performance of the model is very high $\left(\overline{\mathrm{R}}^{2}=0.95\right)$.

Table 1

Sectoral Private Investment $\left(\mathrm{Si}_{\mathrm{t}}\right)$ Expenditure in Processing of Agricultural Products and Food

\begin{tabular}{|c|c|c|c|c|c|}
\hline \multicolumn{3}{|c|}{ C a s e $\quad$ I $^{3}$} & \multicolumn{3}{|c|}{$\begin{array}{llllll} & \text { a } & \text { s } & \text { e } & \text { I } & \text { I } \\
\end{array}$} \\
\hline $\begin{array}{l}\text { Independent } \\
\text { Variables }\end{array}$ & Estimates & $\begin{array}{c}\text { Mean Value } \\
\text { Elasticities }\end{array}$ & $\begin{array}{c}\text { Independent } \\
\text { Variables }\end{array}$ & Estimates & $\begin{array}{c}\text { Mean Value } \\
\text { Elasticities }\end{array}$ \\
\hline Const. & $\begin{array}{c}-1,933,245 \\
(3.43) \\
\end{array}$ & $\begin{array}{l}\cdots \\
\cdots\end{array}$ & Const. & $\begin{array}{c}-253,583.4 \\
(2.38) \\
\end{array}$ & $\begin{array}{l}\cdots \\
\cdots\end{array}$ \\
\hline $\mathbf{E S S}_{\mathbf{t}}$ & $\begin{array}{c}2.33 \\
(16.79) \\
\end{array}$ & $\begin{array}{c}0.66 \\
\ldots\end{array}$ & $\mathbf{E S S}_{\mathbf{t}}$ & $\begin{array}{c}1.81 \\
(19.41) \\
\end{array}$ & 0.51 \\
\hline $\mathbf{N S S}_{\mathbf{t}}$ & $\begin{array}{c}1.794 \\
(12.04)\end{array}$ & $\begin{array}{c}0.39 \\
\ldots\end{array}$ & $\mathrm{NSS}_{\mathrm{t}}$ & $\begin{array}{c}2.22 \\
(16.37)\end{array}$ & $\begin{array}{c}0.49 \\
\ldots\end{array}$ \\
\hline $\mathbf{V A} \mathbf{A}_{t-1}$ & $\begin{array}{l}0.128 \\
(3.34) \\
\end{array}$ & $\begin{array}{c}0.44 \\
\ldots\end{array}$ & $\mathbf{V A}_{t-1}$ & $\begin{array}{c}237,252.8 \\
\quad(1.85) \\
\end{array}$ & $\begin{array}{c}0.023 \\
\ldots\end{array}$ \\
\hline $\mathrm{SI}_{\mathrm{t}-1}$ & $\begin{array}{l}0.076 \\
(5.69)\end{array}$ & $\begin{array}{l}\cdots \\
\cdots\end{array}$ & $\mathrm{SI}_{\mathrm{t}-1}$ & $\begin{array}{c}0.088 \\
(3.943) \\
\end{array}$ & $\begin{array}{c}\ldots \\
\ldots \\
\cdots\end{array}$ \\
\hline$\lambda$ & 0.92 & $\ldots$ & $\lambda$ & 0.91 & $\ldots$ \\
\hline $\mathbf{N}$ & 176 & & $\mathbf{N}$ & 176 & $\ldots$ \\
\hline \multicolumn{3}{|c|}{ Statistics } & \multicolumn{3}{|c|}{ Statistics } \\
\hline$\overline{\mathbf{R}}^{2}$ & 0.95 & $\cdots$ & $\overline{\mathbf{R}}^{2}$ & 0.96 & $\cdots$ \\
\hline
\end{tabular}

Note: Figures in parentheses denote t-statistics. For the first case of the sectoral Estimation, the set of instruments includes $\mathrm{P}$ and its lagged values at time $\mathrm{t}-1, \mathrm{t}-2$ and $\mathrm{t}-3$; the lagged values of ESS, NSS VA and TI at time $\mathrm{t}-1$, $\mathrm{t}-2$ and $\mathrm{t}-3$, and the lagged values at time t-2 and $\mathrm{t}-3$. For the second case of sectoral estimation, the set of instruments include $\mathrm{P}$ and its lagged values at time t-2 and t-3; the lagged values of ESS and NSS; the VA and TI and their lagged values at time t-1, and $\mathrm{t}-3$; and the lagged values of SI at time $\mathrm{t}-1, \mathrm{t}-2$ and $\mathrm{t}-3$.

\footnotetext{
2 Although the rate of interest is included among the explanatory variables on investor's decisions, it is found statistically insignificant.

3 Notice that the only difference between Case I and Case II is that the variable VA $\mathrm{t}_{\mathrm{t}-1}$ in Case I is substituted by $\mathrm{P}_{\mathrm{t}-1}$ in Case II.
} 
Turning now to the investment function for all regions (Table 2), we notice that this is influenced by the value added of processing agricultural products and food or, alternatively, by the level of food prices in the previous year, implying low elasticity value (0.3). The most decisive variables are by far the national and European subsidies based on the statistical significance test. The dynamic process of the investment decision is verified by the statistical significance of investment in the previous year. The partial adjustment coefficient is $\lambda=0.96$, which means that investment adjustment takes place within a little over one year.

Table 2

Regional Private Investment $\left(\mathbf{R i}_{\mathbf{t}}\right)$ in Processing of Agricultural Products and Food

\begin{tabular}{|c|c|c|c|c|c|}
\hline \multicolumn{3}{|c|}{ C a s e I } & \multicolumn{3}{|c|}{ C a s e I I } \\
\hline $\begin{array}{l}\text { Independent } \\
\text { Variables }\end{array}$ & Estimates & $\begin{array}{c}\text { Mean Value } \\
\text { Elasticities }\end{array}$ & $\begin{array}{c}\text { Independent } \\
\text { Variables }\end{array}$ & Estimates & $\begin{array}{c}\text { Mean Value } \\
\text { Elasticities }\end{array}$ \\
\hline Const. & $\begin{array}{c}-1,152,688 \\
(4.56) \\
\end{array}$ & $\begin{array}{l}\ldots \\
\ldots\end{array}$ & Const. & $\begin{array}{c}-388,716.7 \\
(3.06) \\
\end{array}$ & $\begin{array}{l}\ldots \\
\ldots\end{array}$ \\
\hline$\overline{\mathbf{E S S}_{\mathrm{t}}}$ & $\begin{array}{c}1.589 \\
(16.73) \\
\end{array}$ & $\begin{array}{c}0.44 \\
\ldots \\
\end{array}$ & $\overline{\mathbf{E S S}_{\mathbf{t}}}$ & $\begin{array}{c}1.469 \\
(13.51) \\
\end{array}$ & $\begin{array}{c}0.40 \\
\ldots \\
\end{array}$ \\
\hline $\mathbf{N S S}_{\mathbf{t}}$ & $\begin{array}{c}1.936 \\
(16.73) \\
\end{array}$ & $\begin{array}{c}0.43 \\
\ldots \\
\end{array}$ & $\mathbf{N S S}_{\mathbf{t}}$ & $\begin{array}{c}3.15 \\
(23.84) \\
\end{array}$ & $\begin{array}{c}0.70 \\
\ldots \\
\end{array}$ \\
\hline $\mathbf{V A}_{t-1}$ & $\begin{array}{l}0.106 \\
(4.74) \\
\end{array}$ & $\begin{array}{c}0.39 \\
\ldots \\
\end{array}$ & $\mathbf{V A} A_{t-1}$ & $\begin{array}{c}250,581 \\
(3.15) \\
\end{array}$ & $\begin{array}{c}0.025 \\
\ldots \\
\end{array}$ \\
\hline $\mathbf{S I}_{\mathrm{t}-1}$ & $\begin{array}{l}0.038 \\
(2.19) \\
\end{array}$ & $\begin{array}{l}\ldots \\
\ldots\end{array}$ & $\mathbf{S I}_{\mathrm{t}-1}$ & $\begin{array}{r}0.035 \\
(2.564) \\
\end{array}$ & $\begin{array}{l}\ldots \\
\ldots \\
\end{array}$ \\
\hline$\lambda$ & 0.96 & $\ldots$ & $\lambda$ & 0.96 & $\ldots$ \\
\hline $\mathbf{N}$ & 192 & & $\mathbf{N}$ & 192 & $\ldots$ \\
\hline \multicolumn{3}{|c|}{ Statistics } & \multicolumn{3}{|c|}{ Statistics } \\
\hline$\overline{\mathbf{R}}^{2}$ & 0.93 & $\cdots$ & $\overline{\mathbf{R}}^{2}$ & 0.85 & $\cdots$ \\
\hline
\end{tabular}

Note: $\quad$ Figures in parentheses denote t-statistics. For the first case of the regional estimation, the set of instruments inludes $\mathrm{P}$ and its lagged values at time $\mathrm{t}-1, \mathrm{t}-2$ and $\mathrm{t}-3$; the lagged values of ESR, NSR and TI at time $\mathrm{t}-1, \mathrm{t}-2$ and $\mathrm{t}-3$; the VA and its lagged values at time $\mathrm{t}-1, \mathrm{t}-2$ and $\mathrm{t}-3$; and the lagged values of SI at time $\mathrm{t}-2$ and $\mathrm{t}-3$. For the second case of the regional estimation, the set of instruments include TI and VA and their lagged values at time t-1, t-2 and t-3; the lagged values of ESR and NSR; and the lagged values of SI at time t-2 and $t-3$.

\section{The Panel Data Model With Fixed And Random Effects}

Consider a model of the form

$$
\begin{aligned}
& y_{i t}=\gamma \cdot y_{i, t-1}+x_{i t}^{\prime} \beta+v_{i t} \\
& i=1, . ., n, t=1, . ., T \\
& v_{i t}=\alpha_{i}+u_{i t}
\end{aligned}
$$

where $x_{i t}$ is a $k \times 1$ vector of observations for the explanatory variables and $\alpha_{i}$ is an individual effect that may be fixed or random. A random effect formulation is given by the following assumptions:

$$
\begin{aligned}
& E\left(\alpha_{i}\right)=E\left(u_{i t}\right)=E\left(\alpha_{i} x_{i t}^{\prime}\right)=E\left(\alpha_{i} u_{j t}\right)=0 \\
& E\left(\alpha_{i} \alpha_{j}\right)=\left\{\begin{array}{l}
\sigma_{\alpha}^{2}, i=j \\
0, i \neq j
\end{array}\right.
\end{aligned}
$$


$E\left(u_{i t} u_{j t}\right)=\left\{\begin{array}{l}\sigma_{u}^{2}, i=j \\ 0, i \neq j\end{array}\right.$

It is known that in dynamic panel data models the fixed-effects estimator is no longer consistent and, with random effects, consistency and existence of the maximum likelihood estimator depends on the nature of initial conditions and the way in which the time dimension, $\mathrm{T}$, and the cross section dimension, $\mathrm{n}$, tend to infinity. For this reason, alternative formulations should be examined.

One possibility is to consider the initial conditions $\mathrm{y}_{\mathrm{i} 0}$ as fixed, which gives rise to the following likelihood function:

$\mathrm{L}=(2 \pi)^{-\mathrm{nT} / 2}|\mathbf{V}|^{-\mathrm{n} / 2} \exp \left\{-\frac{1}{2} \sum_{\mathrm{i}=1}^{\mathrm{n}}\left(\mathbf{y}_{\mathrm{i}}-\mathbf{y}_{\mathrm{i},-1} \gamma-\mathbf{X}_{\mathrm{i}} \boldsymbol{\beta}\right)^{\prime} \mathbf{V}^{-1}\left(\mathbf{y}_{\mathrm{i}}-\mathbf{y}_{\mathrm{i},-1} \gamma-\mathbf{X}_{\mathrm{i}} \boldsymbol{\beta}\right)\right\}$

where

$$
y_{i}=\left[y_{i 1}, . ., y_{i T}\right]^{\prime}, y_{i,-1}=\left[y_{i 0}, . ., y_{i, T-1}\right]^{\prime}, X_{i}=\left[x_{i 1}, \ldots, x_{i T}\right]^{\prime}, V=\sigma_{u}^{2} I_{T}+\sigma_{\alpha}^{2} e^{\prime}
$$

and $\quad \mathrm{e}$ is an $\mathrm{n} \times 1$ vector of ones. We call this "Case I" in estimations.

Another possibility is to assume that the initial conditions are random, for example, being normally distributed with mean $\mu_{\mathrm{y} 0}$ and variance $\sigma_{\mathrm{y} 0}^{2}$ independently of the $\alpha_{\mathrm{i}}$ 's, where $\mu_{\mathrm{y} 0}$ and $\sigma_{\mathrm{y} 0}^{2}$ are unknown parameters. The likelihood function in this case is given by:

$$
\begin{aligned}
& \mathrm{L}=(2 \pi)^{-\mathrm{nT} / 2}|\mathbf{V}|^{-\mathrm{n} / 2} \exp \left\{-\frac{1}{2} \sum_{\mathrm{i}=1}^{\mathrm{n}}\left(\mathbf{y}_{\mathrm{i}}-\mathbf{y}_{\mathrm{i},-1} \gamma-\mathbf{X}_{\mathrm{i}} \boldsymbol{\beta}\right)^{\prime} \mathbf{V}^{-1}\left(\mathbf{y}_{\mathrm{i}}-\mathbf{y}_{\mathrm{i},-1} \gamma-\mathbf{X}_{\mathrm{i}} \boldsymbol{\beta}\right)\right\} \\
& (2 \pi)^{-\mathrm{n} / 2}\left(\sigma_{\mathrm{y} 0}^{2}\right)^{-\mathrm{n} / 2} \exp \left\{-\frac{1}{2 \sigma_{\mathrm{y} 0}^{2}} \sum_{\mathrm{i}=1}^{\mathrm{n}}\left(\mathrm{y}_{\mathrm{i} 0}-\mu_{\mathrm{y} 0}\right)^{2}\right\}
\end{aligned}
$$

The independence assumption has implications for the consistency of the ML estimator, so a more general assumption is to let $\mathrm{y}_{\mathrm{i} 0}$ be correlated with $\alpha_{\mathrm{i}}$, with covariance given by $\phi^{2} \sigma_{\mathrm{y} 0}^{2}$. In this case, the likelihood function is:

$$
\begin{aligned}
& \mathrm{L}=(2 \pi)^{-\mathrm{nT} / 2}\left(\sigma_{\mathrm{u}}^{2}\right)^{-\mathrm{n}(\mathrm{T}-1) / 2}\left(\sigma_{\mathrm{u}}^{2}+\mathrm{Ta}\right)^{-\mathrm{n} / 2} \exp \left\{-\frac{1}{2 \sigma_{\mathrm{u}}^{2}} \sum_{\mathrm{i}=1}^{\mathrm{n}} \sum_{\mathrm{t}=1}^{\mathrm{T}}\left(\mathrm{y}_{\mathrm{it}}-\gamma \mathrm{y}_{\mathrm{i}, \mathrm{t}-1}-\mathbf{x}_{\mathrm{it}}^{\prime} \boldsymbol{\beta}-\phi\left(\mathrm{y}_{\mathrm{i} 0}-\mu_{\mathrm{y} 0}\right)^{2}\right\}+\right. \\
& \frac{\mathrm{a}}{2 \sigma_{\mathrm{u}}^{2}\left(\sigma_{\mathrm{u}}^{2}+\mathrm{Ta}\right)} \sum_{\mathrm{i}=1}^{\mathrm{n}}\left\{\sum_{\mathrm{t}=1}^{\mathrm{T}}\left(\mathrm{y}_{\mathrm{it}}-\gamma \mathrm{y}_{\mathrm{i}, \mathrm{t}-1}-\mathbf{x}_{\mathrm{it}}^{\prime} \boldsymbol{\beta}-\phi\left(\mathrm{y}_{\mathrm{i} 0}-\mu_{\mathrm{y} 0}\right)^{2}\right\} .\right.
\end{aligned}
$$




$$
(2 \pi)^{-\mathrm{n} / 2}\left(\sigma_{\mathrm{y} 0}^{2}\right)^{-\mathrm{n} / 2} \exp \left\{-\frac{1}{2 \sigma_{\mathrm{y} 0}^{2}} \sum_{\mathrm{i}=1}^{\mathrm{n}}\left(\mathrm{y}_{\mathrm{i} 0}-\mu_{\mathrm{y} 0}\right)^{2}\right\} .
$$

where $\alpha=\sigma_{\alpha}^{2}-\phi^{2} \sigma_{\mathrm{y} 0}^{2}$. The problem is that $a$ could become negative if the likelihood is parametrized directly in terms of the original variances. For this reason, it is better to parametrize in terms of $\phi \sigma_{\mathrm{y} 0}^{2}$ and a new parameter $\theta$ defined by $\sigma_{\alpha}^{2}=\theta^{2}+\phi^{2} \sigma_{\mathrm{y} 0}^{2}$, so that $a=|\theta|$. We call this "Case II". "For estimation purposes, we have used the MAXLIK and OPTMUM modules available in GAUSS.

\section{Empirical Results}

In our attempt to explain investment behaviour in the processing of agricultural products and food, the dynamic panel data model is also estimated using the Maximum Likelihood (ML) method. The results are almost similar to those obtained by the GMM, with the exception that the t statistics are higher in the former case, owing presumably to efficiency gained by imposing correct distributional assumptions by using ML. Also, the alternative assumptions regarding the initial conditions (case I and case II) yield similar results. Since $\mathrm{t}^{*}$ indicates nonsignificance of $\mathrm{y}_{\mathrm{i}, \mathrm{t}-2}$, we conclude that we have no evidence favouring autocorrelation or dynamic misspecification.

In the case of private investment in the processing of agricultural products and food for all sectors, we notice that the Community and national subsidies are the major explanatory variables (Table 3). The coefficients of the value added of processing agricultural products and food, mainly, and, alternatively, the implicit price deflator of agricultural products and food lagged by one year depict the dynamic process of investors' expectations building in a satisfactory manner. In contrast to the results arrived at by the GMM, using the method of ML, the level of private investment in the processing of agricultural products and food in the previous year is statistically insignificant, although it does bear the anticipated sign.

Considering the empirical results of the investment function by region, we notice that they are heavily influenced by the EU and national subsidies (Table 4). Also, the value added of processing of agricultural products and food and, alternatively, agricultural prices exert a strong influence on investment. Finally, investment lagged by one year seems to be a statistically significant variable, indicating the dynamic character of the model. 
Table 3

Dynamic Panel Data Model: ML Results of Sectoral Private Investment Expenditure in Processing gricultural Products and Food $\left(\mathbf{S I}_{t}\right)$

\begin{tabular}{|c|c|c|c|c|c|c|c|c|}
\hline \multirow[b]{2}{*}{$\begin{array}{l}\text { Independent } \\
\text { Variables }\end{array}$} & \multicolumn{4}{|c|}{ C a s e I } & \multicolumn{4}{|c|}{ C a s e I I } \\
\hline & Estimates & $\begin{array}{c}\text { Elasti- } \\
\text { cities }\end{array}$ & Estimates & $\begin{array}{c}\text { Elasti- } \\
\text { cities }\end{array}$ & Estimates & $\begin{array}{c}\text { Elasti- } \\
\text { cities }\end{array}$ & Estimates & $\begin{array}{l}\text { Elasti- } \\
\text { cities }\end{array}$ \\
\hline$\overline{\mathbf{E S S}_{\mathrm{t}}}$ & $\begin{array}{c}1.708 \\
(25.98)\end{array}$ & 0.49 & $\begin{array}{c}1.725 \\
(26.15)\end{array}$ & 0.48 & $\begin{array}{c}1.698 \\
(25.12)\end{array}$ & 0.48 & $\begin{array}{c}1.687 \\
(24.40)\end{array}$ & 0.48 \\
\hline $\mathbf{N S S}_{\mathrm{t}}$ & $\begin{array}{c}2.344 \\
(30.46)\end{array}$ & 0.52 & $\begin{array}{c}2.333 \\
(30.20)\end{array}$ & 0.52 & $\begin{array}{c}2.378 \\
(28.58)\end{array}$ & 0.53 & $\begin{array}{c}2.403 \\
(27.84)\end{array}$ & 0.53 \\
\hline $\mathbf{V A} \mathbf{A}_{t-1}$ & $\begin{array}{l}0.123 \\
(8.89) \\
\end{array}$ & 0.43 & $\ldots$ & $\ldots$ & $\begin{array}{l}0.119 \\
(3.43) \\
\end{array}$ & 0.41 & $\ldots$ & $\cdots$ \\
\hline $\mathbf{P}_{\mathrm{t}-1}$ & $\ldots$ & $\cdots$ & $\begin{array}{c}1.4410^{4} \\
(2.12)\end{array}$ & 0.001 & $\ldots$ & $\ldots$ & $\begin{array}{c}1.4610^{4} \\
(1.52)\end{array}$ & $\cdots$ \\
\hline $\mathbf{S I}_{\mathrm{t}-1}$ & $\begin{array}{l}0.009 \\
(0.31) \\
\end{array}$ & $\ldots$ & $\begin{array}{l}0.019 \\
(1.09) \\
\end{array}$ & $\cdots$ & $\begin{array}{c}0.011 \\
(0.659) \\
\end{array}$ & $\cdots$ & $\begin{array}{l}0.013 \\
(0.79) \\
\end{array}$ & 0.001 \\
\hline$\overline{\mathrm{R}}^{2}$ & 0.30 & $\ldots$ & 0.39 & $\ldots$ & 0.30 & $\ldots$ & 0.41 & $\ldots$ \\
\hline $\mathbf{t}^{*}$ & 1.17 & $\ldots$ & 0.98 & $\ldots$ & 1.23 & $\ldots$ & 1.12 & $\ldots$ \\
\hline
\end{tabular}

Note: Figures in parentheses are t-statistics. $\mathrm{t}^{*}$ denotes the $\mathrm{t}$-statistic of the coefficient of variable $\mathrm{y}_{\mathrm{i}, \mathrm{t}-2}$ when is included formally as a regressor. This can be used as a test for autocorrelation or misspecification. Cases I and II refer to likelihood functions presented in relations (9) and (11) respectively.

Table 4: Dynamic Panel Data Model: ML Results of Regional Private Investment in Processing Agricultural Products and Food $\left(\mathbf{R I}_{\mathbf{t}}\right)$

\begin{tabular}{|c|c|c|c|c|c|c|c|c|}
\hline \multirow[b]{2}{*}{$\begin{array}{l}\text { Independent } \\
\text { Variables }\end{array}$} & \multicolumn{4}{|c|}{ C a s e I } & \multicolumn{4}{|c|}{ C a s e I I } \\
\hline & Estimates & $\begin{array}{c}\text { Elasti- } \\
\text { cities }\end{array}$ & Estimates & $\begin{array}{c}\text { Elasti- } \\
\text { cities }\end{array}$ & Estimates & $\begin{array}{c}\text { Elasti- } \\
\text { cities }\end{array}$ & Estimates & $\begin{array}{l}\text { Elasti- } \\
\text { cities }\end{array}$ \\
\hline ESR $_{t}$ & $\begin{array}{c}1.968 \\
(27.70)\end{array}$ & 0.54 & $\begin{array}{c}1.962 \\
(30.36)\end{array}$ & 0.54 & $\begin{array}{c}1.971 \\
(31.62)\end{array}$ & 0.54 & $\begin{array}{c}1.966 \\
(30.38)\end{array}$ & 0.54 \\
\hline $\mathbf{N S R}_{t}$ & $\begin{array}{c}1.921 \\
(31.30)\end{array}$ & 0.43 & $\begin{array}{c}1.899 \\
(32.21)\end{array}$ & 0.43 & $\begin{array}{c}1.874 \\
(32.58)\end{array}$ & 0.42 & $\begin{array}{c}1.883 \\
(31.47)\end{array}$ & 0.42 \\
\hline $\mathbf{V A} A_{t-1}$ & $\begin{array}{l}0.149 \\
(5.43)\end{array}$ & 0.56 & .. & 0.002 & $\begin{array}{l}0.147 \\
(5.32)\end{array}$ & 0.55 & $\ldots$ & 0.002 \\
\hline $\mathbf{P}_{\mathrm{t}-1}$ & $\ldots$ & $\ldots$ & $\begin{array}{c}2.3810^{4} \\
(1.75)\end{array}$ & $\cdots$ & $\ldots$ & $\ldots$ & $\begin{array}{c}2.3910^{4} \\
(3.19)\end{array}$ & $\cdots$ \\
\hline $\mathbf{R I}_{\mathrm{t}-1}$ & $\begin{array}{l}0.012 \\
(0.62)\end{array}$ & $\ldots$ & $\begin{array}{c}0.030 \\
(1.604)\end{array}$ & $\ldots$ & $\begin{array}{l}0.030 \\
(1.65)\end{array}$ & $\ldots$ & $\begin{array}{l}0.038 \\
(1.97)\end{array}$ & $\cdots$ \\
\hline$\overline{\mathrm{R}}^{2}$ & 0.40 & .. & 0.45 & . & 0.39 & $\ldots$ & 0.45 & $\cdots$ \\
\hline $\mathbf{t}^{*}$ & 1.44 & $\ldots$ & 0.67 & $\ldots$ & 1.52 & $\cdots$ & 0.88 & $\cdots$ \\
\hline
\end{tabular}

Note: Ibid. Table 3.

\section{CONCLUDING REMARKS AND POLICY IMPLICATIONS}

The aim of this research was to quantify Greek investors' behaviour in the industry of processing agricultural products and food at the aggregate level for all sectors and all regions over the period 1981-1999. Investors' behaviour was examined by employing a synthesized traditional model. The dynamic model was estimated using alternative panel data methods, i.e. a common intercept, by employing GMM, and fixed and random effects, using the ML estimation technique. 
From the overall empirical analysis, we may conclude that EU and national subsidies were instrumental in stimulating agricultural investments in the past decades, followed by investors' expectations expressed by the value added of processing agricultural products and food or, alternatively, by agricultural prices. In most of the cases, investment lagged by one year is shown to influence investment decisions. The coefficients of the EU subsidy and national subsidy variables (in most cases range between 1.7 and 2.3) are not surprising, considering the co-financing of the subsidies mentioned in section 2, which often amounts to 50 percent in the case of the EU. This implies a potential endogeneity of the subsidy variable which might be an issue for further research.

Comparing the empirical results obtained by ML with those obtained by GMM we conclude that they are very similar, with the exception that the t-statistics are higher in the former case. Moreover, we have no evidence for autocorrelation or dynamic misspecification.

\section{SUGGESTIONS FOR FUTURE RESEARCH}

Perhaps it would be interesting to estimate the GMM model considering not only a common intercept but also a fixed effects model, with a different constant for each region. It would be also interesting to consider a Seemingly Unrelated Regression model to estimate investment functions with a block of zeros in the coefficient matrix.

\section{ACKNOWLEDGEMENTS}

I am greatly indebted to K. Karras for the data collection, computational assistance with the estimation of the dynamic panel data and for his overall help in this endeavour. I express my appreciation and thanks to $\mathrm{E}$. Tsionas for his valuable contribution on the econometric part of this research. Many thanks are also due to D. Gale Johnson, E. Kyriazidou and A. Andrikopoulos who red this paper and they gave me interesting feedbacks. I gratefully acknowledge the financial support provided by the European Commission.

\section{REFERENCES}

1. Arellano, M., and Honoré, B., Panel Data Models: Some Recent Developments, In Handbook of Econometrics, Vol. 5 (forthcoming), 2002.

2. Arellano, M., and Bond, S., Some Tests of Specification for Panel Data: Monte Carlo Evidence and an Application to Employment Equation, Review of Economic Studies, Vol. 58 No. 2, pp. 277-297, 1991.

3. Baltagi, B.H., Econometric Analysis of Panel Data, New York, Wiley, 1996.

4. Baltas, N.C., Private Investment and the Demand for Loanable Funds in the Greek Agricultural Sector, Journal of Policy Modeling, Vol. 21, No. 1, pp. 67-88, 1999.

5. Berndt, E., Fuss, M., and Waverman, L., Dynamic Models of the Industrial Demand for Energy, Palo Alto, CA: Electric Power Research Institute, 1978.

6. Cambell, K.O., Some Reflections on Agricultural Investment, Australian Journal of Agricultural Economics, Vol. 2, pp. 93-103, 1958.

7. Cassing, S. and Kollintzas, T., Recursive Factor of Production Interrelations and Endogenous Cycling, International Economic Review, Vol. 32, No. 2, pp. 417-440, 1991.

8. Chamber of Industry and Commerce of Athens (CICA), Panorama of Economic Activity, Athens, 1998.

9. Clark, J.M., Business Accelerations in the Law of Demand: A Technical Factor in Economic Cycles, Journal of Political Economy, Vol. 25, pp. 217-235, 1917.

10. European Commission, Panorama of European Business, Eurostat, Luxembourg, 2002.

11. Girao, J.A., Tomek, W.G, and Mount, T.D., The Effect of Income Instability on Farmers' Consumption and Investment, Revue of Economics and Statistics, Vol. 56, pp. 141-150, 1974.

12. Jorgenson, D.W., Economic Studies of Investment Behavior: A Survey, Journal of Economics Literature, Vol. 49, pp. 1111-1147, 1971.

13. Jorgenson, D.W., and Siebert, C.D., A Comparison of Alternative Theories of Corporate Investment Behavior, American Economic Revue, Vol. 58, pp. 681-712, 1968.

14. Koyck, L.H., Distributed Lags and Investment Analysis, Amsterdam: North-Holland Publishing Co., 1954. 
15. LeBlank, M., and Hrubovcak, J., The Effects of Interest Rates on Agricultural Machinery Investment, Agricultural Economic Research, Vol. 37, pp. 12-22, 1985.

16. LeBlank, M., and Hrubovcak, J., The Effects of Tax Policy on Aggregate Agricultural Investment, American Journal of Agricultural Economics, Vol.68, pp. 767-777, 1986.

17. Mulkay, B., Hall, B. and Mairesse, J., Firm Level Investment and R\&D in France and the United States: A Comparison, Economic Papers 2001-W2, Economics Group, Nuffield College, University of Oxford, 2001.

18. Morrison, C.J., Structural Change, Capital Investment and Productivity in the Food Processing Industry, American Journal of Agricultural Economics, Vol. 79, No. 1, pp. 110-125, 1988.

19. Morrison, C.J. and Siegel, D., Knowledge Capital and Cost Structure in the U.S. Food and Fiber Industries, American Journal of Agricultural Economics, Vol. 79, No. 4, pp. 647-654, 1977.

20. Tinbergen, J., Statistical Evidence of the Acceleration Principle, Econometrics, Vol. 5, pp. 164-176, 1938.

21. Treveno, B.J., and Keller, L.H., Estimating the Investment Behavior for Farm Firms Using the Concept of Rational Distributed Lag Functions, Southern Journal of Agricultural Economic, Vol. 6, pp. 111-116, 1974.

22. Weersink, A.J., and Tauer, L.W., Comparative Analysis of Investment Models for New York Dairy Farms, American Journal of Agricultural Economics, Vol. 71, pp. 136-145, 1989.

\section{Appendix}

\section{Abbreviations of Variables}

\begin{tabular}{|c|c|}
\hline ABBR. & DESCRIPTION \\
\hline RI & $\begin{array}{l}\text { Investment by region deflated by implicit price index of investment in the processing of agricultural products and } \\
\text { food }\end{array}$ \\
\hline SI & $\begin{array}{l}\text { Investment by sector deflated by implicit price index of investment in the processing of agricultural products and } \\
\text { food }\end{array}$ \\
\hline SR & $\begin{array}{l}\text { Total subsidies by region deflated by implicit price index of investment in the processing of agricultural products } \\
\text { and food }\end{array}$ \\
\hline ESR & $\begin{array}{l}\text { E.U. subsidies by region deflated by implicit price index of investment in the processing of agricultural products } \\
\text { and food }\end{array}$ \\
\hline NSR & $\begin{array}{l}\text { National subsidies by region deflated by implicit price index of investment in the processing of agricultural } \\
\text { products and food }\end{array}$ \\
\hline SS & $\begin{array}{l}\text { Total subsidies by sector deflated by implicit price index of investment in the processing of agricultural products } \\
\text { and food }\end{array}$ \\
\hline ESS & $\begin{array}{l}\text { E.U. subsidies by sector deflated by implicit price index of investment in the processing of agricultural products } \\
\text { and food }\end{array}$ \\
\hline NSS & $\begin{array}{l}\text { National subsidies by sector deflated by implicit price index of investment in the processing of agricultural } \\
\text { products and food }\end{array}$ \\
\hline $\mathbf{r}$ & Medium and long-term interest rate for agricultural loans \\
\hline VA & Value added of processing of agricultural products and food at constant 1995 prices \\
\hline $\mathbf{P}$ & Price index of processing of agricultural products and food deflated by implicit price GDP index \\
\hline TI & Total investment for processing of agricultural products and food at constant 1995 prices \\
\hline
\end{tabular}

